\title{
Unexpected transformations of an azoxyquinoxaline
}

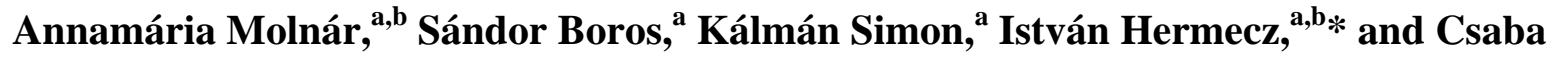 \\ Gönczi $^{\text {a }}$ \\ ${ }^{a}$ Chinoin Ltd, Tó utca 1-5, H-1045 Budapest, Hungary \\ ${ }^{b}$ Department of Organic Chemistry and Technology, Budapest University of Technology and \\ Economics, Budafoki út 8, H-1111 Budapest, Hungary \\ E-mail: Istvan-EXT.Hermecz@sanofi-aventis.com
}

\begin{abstract}
Treatment of $N, N^{\prime}$-di(quinoxalin-2-yl)diazene $N$-oxide 3 with strong acids did not give the expected Wallach-type hydroxylated product, but the first representative of the pentacyclic imidazo[1,2-a:4,5- $b$ ']diquinoxaline system 5. Heating in a weaker acid or neat furnished 1(quinoxalin-2-yl)quinoxalin-2(1H)-one 12. The structures of these products were confirmed by independent synthesis and NMR experiments or X-ray crystallography.
\end{abstract}

Keywords: Nitrogen heterocycles, azoxy compound, thermal transformation, acid catalyzed transformation, rearrangement

\section{Introduction}

Treatment of azoxybenzene $\mathbf{1}$ and its derivatives with certain strong acids is known to result in the corresponding hydroxyazobenzene 2 (Scheme 1). ${ }^{1}$ This rearrangement, discovered by Wallach, was named after him. ${ }^{2}$ The products of the Wallach transformation have been found to depend on the reaction conditions: the hydroxyl group generally appears in a para position, though the application of photochemical ${ }^{3}$ or Lewis acid-catalysed ${ }^{4}$ reactions or blocking of both para positions ${ }^{5}$ leads to the formation of ortho-hydroxy derivatives. Kinetic studies have resulted in much mechanistic information being deduced from the structural changes in the azoxybenzene $^{6}$ and azoxynaphthalene series, ${ }^{7}$ but extension of such studies to the heterocyclic azoxy compounds has not been systematically reported. Only the phenylazoxypyridines and their $N$-oxides were investigated by Buncel and his coworkers. ${ }^{8}$ We set out to extend the generic Wallach rearrangement to heterobicyclic ring systems, and started our investigations with azoxyquinoxaline $3 ;^{9}$ this revealed some interesting and surprising reactions and products, depending on the reaction media. This short paper reports our findings. 


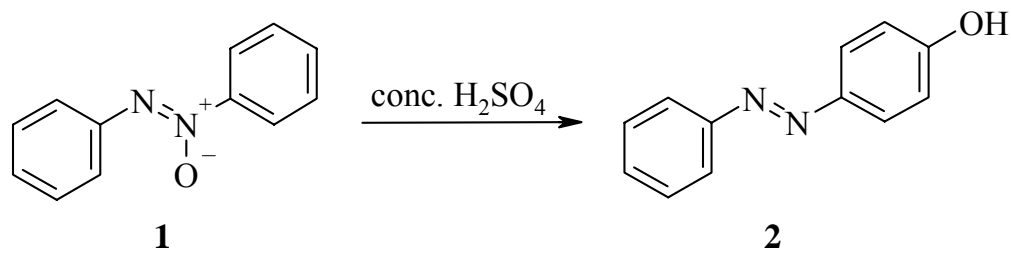

Scheme 1. Wallach rearrangement.

\section{Results and Discussion}

We first applied the original Wallach rearrangement conditions, treating azoxy compound $\mathbf{3}$ with conc. sulfuric acid in the expectation of obtaining the corresponding 3-oxo (ortho-like product, 4a) or 6-hydroxy (para-like product, $4 \mathbf{b}$ ) azo compound (Scheme 2).

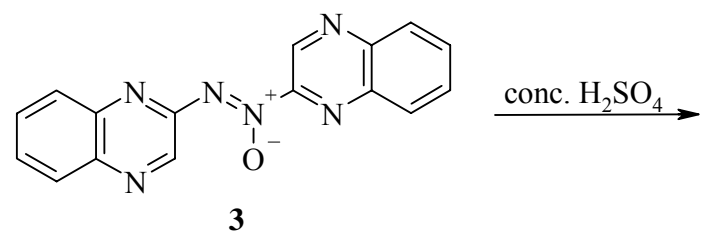

3

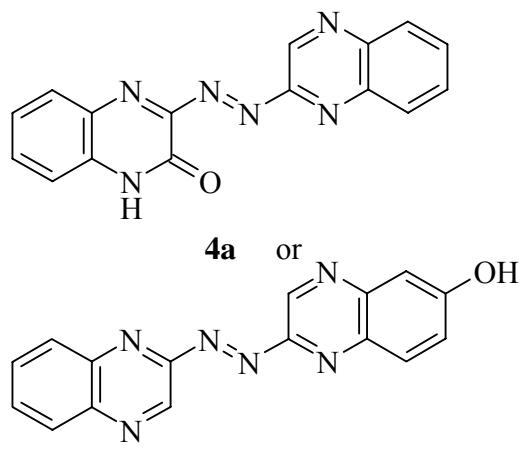

4b

Scheme 2. Expected reaction of 3 in conc. sulfuric acid.

Buncel and his coworkers reported that the phenylazoxypyridines and their $N$-oxides react much more slowly than does azoxybenzene itself, presumably because of the extra positive charge present in the substrates. ${ }^{8}$ We therefore decided to carry out the transformation of 3 at higher temperature. After azoxyquinoxaline 3 had been stirred in conc. sulfuric acid at $140{ }^{\circ} \mathrm{C}$ for $10 \mathrm{~min}$, the isolated product was recrystallized and characterized by HRMS assay. Surprisingly, we observed nitrous gas evolution and, consistently, HRMS assay did not contain any $\mathrm{O}$ atom: instead of the Wallach rearrangement, formally "HNO" was eliminated from 3. Compound 5, with the molecular formula $\mathrm{C}_{16} \mathrm{H}_{9} \mathrm{~N}_{5}$, was obtained in $63 \%$ yield (Scheme 3). On the basis of 2D NMR measurements, a new pentacyclic system, imidazo[1,2-a:4,5$b^{\prime}$ ']diquinoxaline 5 , is proposed for the structure.

This structure was supported by an independent synthesis starting from 2,3dichloroquinoxaline 6 and 2-aminoquinoxaline 7, subjected to the Buchwald-Hartwig protocol, ${ }^{10}$ yielding compound 5 in $43 \%$. The synthesis was also carried out in a two-step reaction. The 
nucleophilic substitution of compound 6 with amine 7 gave 1-(3'-chloro-2'quinoxalinyl)quinoxalin-2(1H)-imine 8, which underwent the Buchwald-Hartwig cyclization ${ }^{10}$ to yield pentacyclic compound 5 .

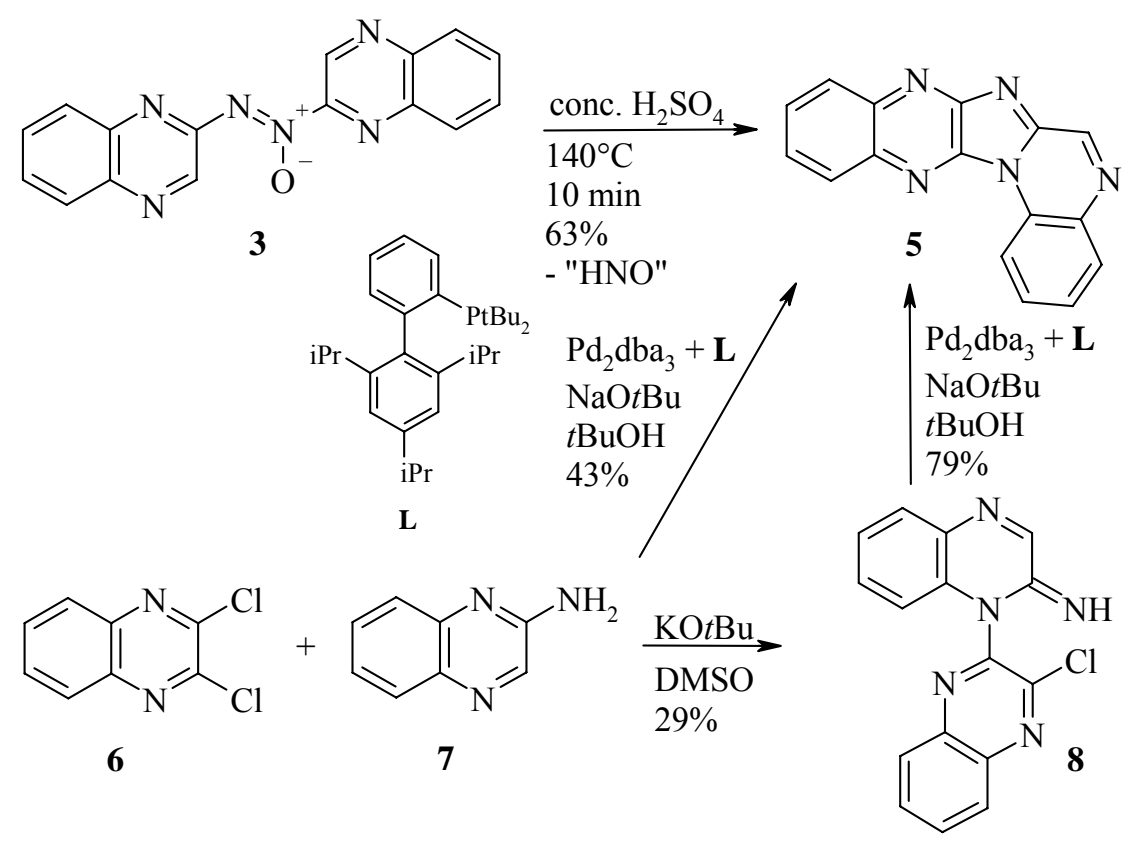

Scheme 3. Formation of 5.

Table 1. Influence of the nature of the acid and temperature on the transformation of 3

\begin{tabular}{cccccc}
\hline Entry & Medium & $p K_{a}$ & $T\left[{ }^{\circ} \mathrm{C}\right]$ & Product & Yield [\%] $]^{\mathrm{a}}$ \\
\hline 1 & conc. $\mathrm{H}_{2} \mathrm{SO}_{4}$ & -3.0 & 140 & $\mathbf{5}$ & 63 \\
2 & conc. $\mathrm{H}_{2} \mathrm{SO}_{4}$ & -3.0 & r.t. & $\mathbf{5}$ & $67^{\mathrm{b}}$ \\
3 & $\mathrm{CH}_{3} \mathrm{SO}_{3} \mathrm{H}$ & -2.6 & 140 & $\mathbf{5}$ & 56 \\
4 & $\mathrm{CF}_{3} \mathrm{COOH}$ & -0.25 & $72^{\mathrm{c}}$ & $\mathbf{5}$ & 56 \\
5 & $\mathrm{HCOOH}$ & 3.77 & $101^{\mathrm{c}}$ & $\mathbf{5}$ & 67 \\
6 & $\mathrm{AcOH}$ & 4.76 & $118^{\mathrm{c}}$ & $\mathbf{1 2}$ & 85 \\
7 & $\mathrm{Ac} 2 \mathrm{O}$ & - & $140^{\mathrm{c}}$ & $\mathbf{1 2}$ & 87 \\
8 & glycol & - & 140 & $\mathbf{1 2}$ & 80 \\
9 & morpholine & - & $129^{\mathrm{c}}$ & $\mathbf{1 6}$ & 87 \\
\hline
\end{tabular}

${ }^{a}$ Reaction time 10 min; yield after isolation and recrystallization.

${ }^{\mathrm{b}}$ Reaction time $48 \mathrm{~h}$.

${ }^{\mathrm{c}}$ At boiling temperature.

Various strong mineral and organic acids uniformly furnished 5 (Table 1, Entries 1-5). In the presence of sulfuric acid, a reduction of the temperature did not have a significant influence on 
the nature or quantity of the product, but the necessary reaction time increased considerably, from $10 \mathrm{~min}$ to $48 \mathrm{~h}$ (Entry 2).

A possible formation of pentacyclic derivative 5 is depicted in Scheme 4. In the protonated form 9, 1,2-aryl migration occurred on the diazo moiety, followed by "HNO" loss to give a di(quinoxalin-2-yl)amino cation 10. Then the pentacyclic skeleton $\mathbf{1 1}$ was formed by electrocyclization of $\mathbf{1 0}$, and after deprotonation pentacycle $\mathbf{5}$ was obtained.

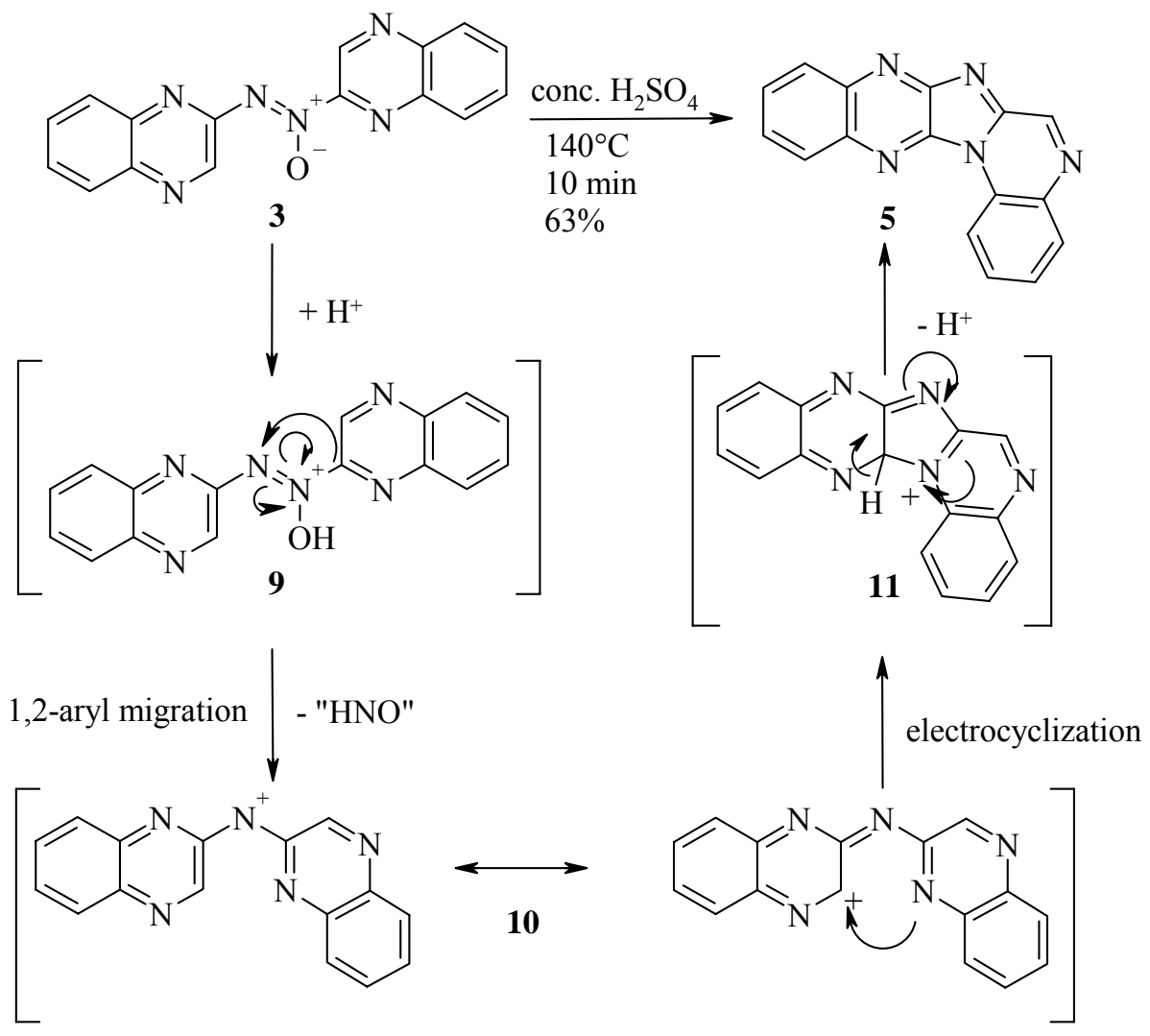

Scheme 4. Proposed mechanism of the acid catalyzed reaction of 3.

When the value of $p K_{a}$ was systematically increased, dramatic changes were observed above $p K_{a}$ 3.77. Reaction in boiling acetic acid provided 12 instead of 5 (Entry 6, Scheme 5). The HRMS assay indicated the elimination of $\mathrm{N}_{2}$ from 3 to yield quinoxalinylquinoxalinone 12. Its structure was proved by X-ray crystallography: the relative positions of the two planar quinoxaline rings are characterized by a C12-N11-C3-C2 of a torsion angle of $63.2(2)^{\circ}$ (Figure 1). ${ }^{11}$ Quinoxalinylquinoxalinone 12 was earlier isolated by Iijima: heating of quinoxaline $N$ oxide with acetic anhydride resulted in formation $12(4 \%)$ among others. ${ }^{12}$ 


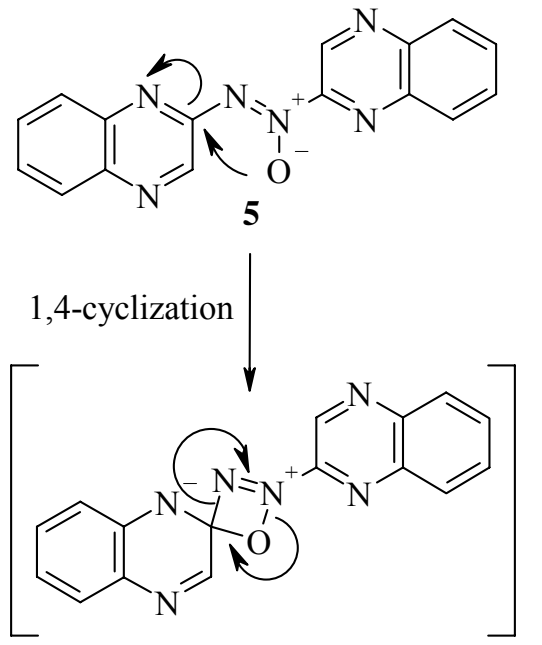

13

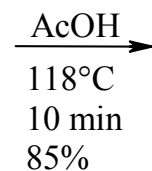<smiles>O=c1cnc2ccccc2n1-c1cnc2ccccc2n1</smiles>

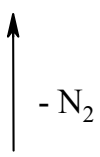

\section{[2+2] cyclo-} reversion

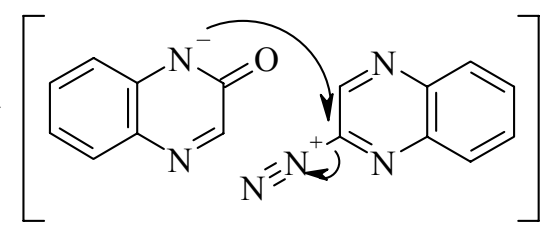

14 15

Scheme 5. Proposed mechanism of the thermal reaction of 3.

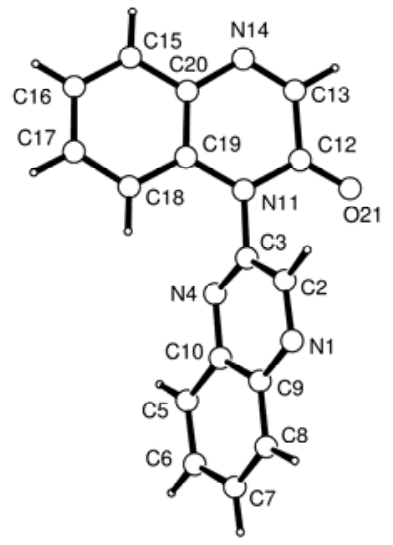

Figure 1. Structure of compound 12 with the crystallographic atomic numbering.

The question arose of the possibility of thermal reaction; the same product was obtained from neutral organic solvents (Entries 7 and 8) and even neat from 3. Accordingly, we carried out thermoanalytical studies (DSC, TG and DTG). At the melting point of $\mathbf{3}$, an intense exothermic reaction $\left(3 \rightarrow 12, \Delta H_{166^{\circ} \mathrm{C}}=84.6 \mathrm{kcal} / \mathrm{mol}\right)$ was detected, and the gravimetry demonstrated a relative loss of mass $\Delta m_{172^{\circ} \mathrm{C}}=9.3 \%$, which is consistent with $\mathrm{N}_{2}$ elimination (theoretical loss: $\Delta m=9.3 \%$ ). When the same sample (now containing quinoxalinylquinoxalinone 12) was further heated to $220{ }^{\circ} \mathrm{C}$, endothermic melting $\left(\Delta H_{220^{\circ} \mathrm{C}}=7.2 \mathrm{kcal} / \mathrm{mol}\right)$ ensued. In solvents, the $\mathrm{N}_{2}$ elimination proceeded even at lower temperatures, indicating a very strong solvent effect (Entries 6-8). This type of thermal transformation does not appear to have been widely described 
in the literature: only one example of the thermolytic loss of $\mathrm{N}_{2}$ from azoxy compounds is known. ${ }^{13}$

On the evidence of these studies and the literature data, we propose the mechanistic pathway depicted in Scheme 5. The first step involves ipso-attack by the oxygen of the azoxy moiety of 3 on the positively charged $\mathrm{C} 2$ of the more distant quinoxaline ring to furnish spiro derivative 13. This is followed by a [2+2]-cycloreversion of intermediate $\mathbf{1 3}$ to give quinoxalinone anion $\mathbf{1 4}$ and quinoxaline-3-diazonium ion 15. $\mathrm{N}_{2}$ loss occurred during recombination of cation $\mathbf{1 5}$ and anion 14 providing quinoxalinylquinoxalinone 12.

To find support for the proposed mechanism we attempted to trap cationic species by a nucleophile. In view of the scope and limitations of the trapping reaction, we set out to catch cation 15 in morpholine. When 3 was heated in boiling morpholine, 2-(morpholin-4yl)quinoxaline $\mathbf{1 6}$ was obtained in good yield (Entry 9, Scheme 6). ${ }^{14}$ Similar treatment of 12 for $10 \mathrm{~min}$ resulted in the formation of $<1 \%$ of $\mathbf{1 6}$.

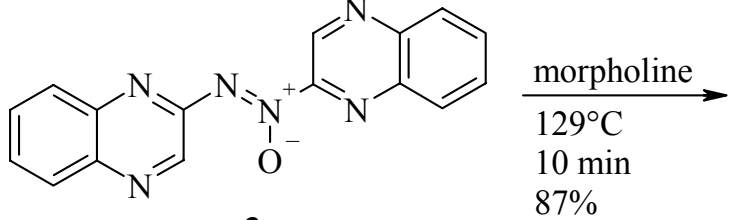

3<smiles>c1ccc2nc(N3CCOCC3)cnc2c1</smiles>

16

Scheme 6. Formation of 16.

\section{Conclusions}

In summary, the treatment of azoxy compound 3 with strong acids or thermally led to two different reaction pathways, furnishing pentacyclic system 5 and quinoxalinylquinoxalinone 12. The structures of the products were supported by detailed NMR analysis, and confirmed by independent synthesis (for 5) and X-ray crystallography (for 12). A possible interpretation of the formations of products $\mathbf{5}$ and $\mathbf{1 2}$ is proposed.

\section{Experimental Section}

General. Melting points were determined in open capillary tubes with a Büchi 535 apparatus and are uncorrected. NMR spectra were measured with a Bruker Avance 500, Avance 400 or Avance 200 instrument, mass spectra (GC-MS) with a Shimadzu GCMS-QP2010S instrument, highresolution mass spectra with a Waters LCT Premier XE instrument, and IR spectra with a VERTEX 70 instrument (KBr). 
$\boldsymbol{N}, \boldsymbol{N}^{\prime}$-Di(quinoxalin-2-yl)diazene $\boldsymbol{N}$-oxide (3). Compound $\mathbf{3}$ was prepared as described in method b) in ref. 9 . The product was found to be identical.

\section{Imidazo[1,2-a:4,5- $b$ ']diquinoxaline (5)}

Method A. A suspension of 3 (300 mg, $1 \mathrm{mmol})$ in conc. sulfuric acid (1 mL) was stirred at 140 ${ }^{\circ} \mathrm{C}$ for $10 \mathrm{~min}$. The reaction mixture was then cooled to room temperature and poured into $\mathrm{NaHCO}_{3}$ solution, after which the precipitate was filtered off. The crude product was recrystallized from methanol. Yield $171 \mathrm{mg}, 63 \%$; orange crystals (from methanol); mp 243-245 ${ }^{\circ} \mathrm{C}$.

Method B. A solution of 8 (308 $\mathrm{mg}, 1 \mathrm{mmol})$, sodium tert-butoxide (198 $\mathrm{mg}, 2 \mathrm{mmol}$ ), phosphine ligand $\mathbf{L}(22 \mathrm{mg}, 0.05 \mathrm{mmol})$ and $\mathrm{Pd}_{2} \mathrm{dba}_{3}(46 \mathrm{mg}, 0.05 \mathrm{mmol})$ in tert-butanol $(2 \mathrm{~mL})$ was stirred at $70{ }^{\circ} \mathrm{C}$ for $24 \mathrm{~h}$. The reaction mixture was cooled to room temperature and was purified by prep. TLC (Kieselgel $60 \mathrm{~F}_{254}, 2 \mathrm{~mm}$, toluene : methanol = $4: 1$ ). The product was recrystallized from methanol. Yield $214 \mathrm{mg}, 79 \%$; orange crystals (from methanol); mp 244-245 ${ }^{\circ} \mathrm{C}$.

Method C. A solution of 6 (207 mg, $1 \mathrm{mmol}), 7$ (160 mg, $1.1 \mathrm{mmol})$, sodium tert-butoxide (218 $\mathrm{mg}, 2.2 \mathrm{mmol}$ ), phosphine ligand $\mathbf{L}(22 \mathrm{mg}, 0.05 \mathrm{mmol})$ and $\mathrm{Pd}_{2} \mathrm{dba}_{3}(46 \mathrm{mg}, 0.05 \mathrm{mmol})$ in tertbutanol $(2 \mathrm{~mL})$ was stirred at $70{ }^{\circ} \mathrm{C}$ for $24 \mathrm{~h}$. The reaction mixture was cooled to room temperature and was purified by prep. TLC (Kieselgel $60 \mathrm{~F}_{254}, 2 \mathrm{~mm}$, toluene : methanol = $4: 1$ ). The product was recrystallized from methanol. Yield $117 \mathrm{mg}, 43 \%$; orange crystals (from methanol); mp 244-245 ${ }^{\circ} \mathrm{C} ;{ }^{1} \mathrm{H} \mathrm{NMR}\left(400 \mathrm{MHz}, \mathrm{CDCl}_{3}, 27{ }^{\circ} \mathrm{C}\right) \delta 9.57\left(\mathrm{~d},{ }^{3} J_{\mathrm{H}, \mathrm{H}}=8.2 \mathrm{~Hz}, 1 \mathrm{H}, 1-\right.$ $\mathrm{H}), 9.37(\mathrm{~s}, 1 \mathrm{H}, 6-\mathrm{H}), 8.37$ and $8.34(\mathrm{~m}, 2 \mathrm{H}, 12-\mathrm{H}$ and $9-\mathrm{H}), 8.18\left(\mathrm{~d},{ }^{3} J_{\mathrm{H}, \mathrm{H}}=8.0 \mathrm{~Hz}, 1 \mathrm{H}, 4-\mathrm{H}\right)$, 7.88 and $7.86(\mathrm{~m}, 3 \mathrm{H}, \mathrm{H}-10, \mathrm{H}-11$ and $2-\mathrm{H}), 7.66\left(\mathrm{dd},{ }^{3} J_{\mathrm{H}, \mathrm{H}}=8.0 \mathrm{~Hz},{ }^{3} J_{\mathrm{H}, \mathrm{H}}=7.4 \mathrm{~Hz}, 1 \mathrm{H}, 3-\mathrm{H}\right)$; ${ }^{13} \mathrm{C} \mathrm{NMR}\left(100 \mathrm{MHz}, \mathrm{CDCl}_{3}, 27{ }^{\circ} \mathrm{C}\right): \delta 148.9(7 a-\mathrm{C}), 146.1(6 a-\mathrm{C}), 146.0(6-\mathrm{C}), 142.9(8 a-\mathrm{C}$ or $12 a-\mathrm{C}), 140.0$ (8a-C or $12 a-\mathrm{C}), 138.2$ (13a-C), 135.2 (4a-C), 131.5 (2-C), 130.9 (4-C), 129.8 (9$\mathrm{C}$ or 12-C), 129.4 (10-C or 11-C), 129.3 (10-C or 11-C), 128.8 (9-C or 12-C), 128.1 (13c-C), 126.7 (3-C), 116.9 (1-C); MS(EI+) $m / z=271\left[\mathrm{M}^{+}\right], 244,143,129 ; \mathrm{HRMS}(\mathrm{ES}+) \mathrm{m} / z=272.0919$ $\left[\mathrm{MH}^{+}\right]$, calcd. for $\mathrm{C}_{16} \mathrm{H}_{10} \mathrm{~N}_{5}^{+} 272.0936$.

1-(3'-Chloro-2'-quinoxalinyl)quinoxalin-2(1H)-imine (8). A solution of 6 (218 $\mathrm{mg}, 1.05$ $\mathrm{mmol}), 7$ (145 mg, $1 \mathrm{mmol})$ and potassium tert-butoxide $(118 \mathrm{mg}, 1 \mathrm{mmol})$ in DMSO (1.5 mL) was stirred at room temperature for $3 \mathrm{~h}$. The reaction mixture was poured into water $(7.5 \mathrm{~mL})$, the precipitate was filtered off. The crude product was recrystallized from acetonitrile. Yield 103 mg, 33\%; purity: 83\% (HPLC); yellow crystals (from acetonitrile); mp $196{ }^{\circ} \mathrm{C} .{ }^{1} \mathrm{H}$ NMR (400 MHz, DMSO- $\left.d_{6}, 27^{\circ} \mathrm{C}\right) \delta 10,17(\mathrm{br}, 1 \mathrm{H}, \mathrm{NH}), 9.57$ (br, $\left.1 \mathrm{H}, 3-\mathrm{H}\right), 8.06\left(\mathrm{~d},{ }^{3} J_{\mathrm{H}, \mathrm{H}}=8.4 \mathrm{~Hz}, 1 \mathrm{H}\right.$, 5-H), $7.96\left(\mathrm{~d},{ }^{3} J_{\mathrm{H}, \mathrm{H}}=8.0 \mathrm{~Hz}, 1 \mathrm{H}, 5^{\prime}-\mathrm{H}\right), 7.90$ and $7.88\left(\mathrm{~m}, 2 \mathrm{H}, 8-\mathrm{H}\right.$ and $\left.8^{\prime}-\mathrm{H}\right), 7.80$ and 7.79 $\left(\mathrm{m}, 2 \mathrm{H}, 7-\mathrm{H}\right.$ and $\left.7^{\prime}-\mathrm{H}\right), 7.71$ and $7.69\left(\mathrm{~m}, 2 \mathrm{H}, 6-\mathrm{H}\right.$ and $\left.6^{\prime}-\mathrm{H}\right) ;{ }^{13} \mathrm{C}$ NMR (100 MHz, DMSO- $d_{6}$, $\left.27^{\circ} \mathrm{C}\right) \delta 148.4$ (2-C), 145.4 (2'-C or 4a'-C), 141.3 (br, 3-C), 140.8 (8a-C), 140.3 (3'-C), 139.4 (8a'-C), 138.9 (4a-C), 138.1 (4a'-C or 2'-C), 131.0 (7'-C), 130.7 (7-C), 128.9 (5-C), 128.0 (6'C), 127.8 (6-C), 127.75 (5'-C), 127.1 (br, 8-C), 126.8 (8'-C); MS(EI+) $m / z=271$ [M-HCl] ${ }^{+}, 143$, 129, 102; HRMS(ES+) $m / z=308.0707\left[\mathrm{MH}^{+}\right]$, calcd. for $\mathrm{C}_{16} \mathrm{H}_{11} \mathrm{ClN}_{5}{ }^{+}$308.0703. 
1-(Quinoxalin-2-yl)quinoxalin-2(1H)-one (12). A suspension of 3 (300 mg, $1 \mathrm{mmol}$ ) in acetic anhydride $(1 \mathrm{~mL})$ was stirred at the boiling point for $10 \mathrm{~min}$. The reaction mixture was then cooled to room temperature and poured into $\mathrm{NaHCO}_{3}$ solution, after which the precipitate was filtered off. The crude product was recrystallized from methanol. Yield $238 \mathrm{mg}, 87 \%$; yellow crystals; mp 222-223 ${ }^{\circ} \mathrm{C}$ (lit. ${ }^{12} \mathrm{mp} 218{ }^{\circ} \mathrm{C}$ ); ${ }^{1} \mathrm{H}$ NMR $\left(400 \mathrm{MHz}, \mathrm{DMSO}-d_{6}, 27{ }^{\circ} \mathrm{C}\right) \delta 9.20(\mathrm{~s}, 1$ H, 3'-H), $8.44(\mathrm{~s}, 1 \mathrm{H}, 3-\mathrm{H}), 8.30\left(\mathrm{~d},{ }^{3} J_{\mathrm{H}, \mathrm{H}}=8.1 \mathrm{~Hz}, 1 \mathrm{H}, 5^{\prime}-\mathrm{H}\right), 8.20\left(\mathrm{~d},{ }^{3} J_{\mathrm{H}, \mathrm{H}}=7.8 \mathrm{~Hz}, 1 \mathrm{H}, 8^{\prime}-\right.$ H), 8.06 and $8.02\left(\mathrm{~m}, 2 \mathrm{H}, 6^{\prime}-\mathrm{H}\right.$ and $\left.7^{\prime}-\mathrm{H}\right), 7.96\left(\mathrm{~d},{ }^{3} J_{\mathrm{H}, \mathrm{H}}=7.6 \mathrm{~Hz}, 1 \mathrm{H}, 5-\mathrm{H}\right), 7.48$ and $7.44(\mathrm{~m}$, $2 \mathrm{H}, 7-\mathrm{H}$ and 6-H), $6.92\left(\mathrm{~d},{ }^{3} J_{\mathrm{H}, \mathrm{H}}=8.1 \mathrm{~Hz}, 1 \mathrm{H}, 8-\mathrm{H}\right) ;{ }^{13} \mathrm{C}$ NMR $\left(100 \mathrm{MHz}, \mathrm{DMSO}-d_{6}, 27{ }^{\circ} \mathrm{C}\right) \delta$ 154.7 (2-C), 151.3 (3-C), 146.1 (3'-C), 145.0 (2’'-C), 142.2 (4a'-C), 141.5 (8a'-C), 132.8 (8a-C), 132.7 (4a-C), 132.2 (6'-C), 131.8 (7'-C), 131.6 (7-C), 130.1 (5-C), 129.5 (2 C, 5'-C and 8'-C), 124.8 (6-C), 115.8 (8-C); MS(EI+) $m / z=274\left[\mathrm{M}^{+}\right], 273,245,219 ; \mathrm{HRMS}(\mathrm{ES}+) \mathrm{m} / z=275.0927$ $\left[\mathrm{MH}^{+}\right]$, calcd. for $\mathrm{C}_{16} \mathrm{H}_{11} \mathrm{~N}_{4} \mathrm{O}^{+} 275.0933$; IR(KBr) $1667 \mathrm{~cm}^{-1}$ ( $\left.v_{\text {amide }} \mathrm{C}=\mathrm{O}\right)$.

2-(Morpholin-4-yl)quinoxaline (16). A solution of 3 (300 mg, $1 \mathrm{mmol})$ in morpholine (1 mL) was stirred at the boiling point for $10 \mathrm{~min}$. The reaction mixture was then cooled to room temperature and purified by prep. TLC (Kieselgel $60 \mathrm{~F}_{254}, 2 \mathrm{~mm}$, hexane : EtOAc = 1: 1). The product was recrystallized from methanol. Yield $187 \mathrm{mg}, 87 \%$; red crystals; mp $85-87{ }^{\circ} \mathrm{C}$ (lit. ${ }^{14}$ mp 88-89 $\left.{ }^{\circ} \mathrm{C}\right) ;{ }^{1} \mathrm{H}$ NMR $\left(200 \mathrm{MHz}, \mathrm{DMSO}-d_{6}, 27^{\circ} \mathrm{C}\right) \delta 8.81(\mathrm{~s}, 1 \mathrm{H}, 3-\mathrm{H}), 7.84\left(\mathrm{~d},{ }^{3} J_{\mathrm{H}, \mathrm{H}}=8.2\right.$ $\mathrm{Hz}, 1 \mathrm{H}, 5-\mathrm{H}), 7.64-7.54$ (m, $2 \mathrm{H}, 8-\mathrm{H}$ and 7-H), 7.47-7.43 (m, $1 \mathrm{H}, 6-\mathrm{H}), 3.73$ (br, 8 H, 2'-H and $\left.3^{\prime}-\mathrm{H}\right) ;{ }^{13} \mathrm{C}$ NMR (50 MHz, DMSO- $\left.d_{6}, 27{ }^{\circ} \mathrm{C}\right) \delta 152.6(2-\mathrm{C}), 141.4(8 a-\mathrm{C}), 137.2$ (3-C), 136.8 (4a-C), 130.4 (7-C), 128.8 (5-C), 126.5 (8-C), 125.0 (6-C), 66.3 (2 C, 2'-C), 44.9 (2 C, 3'-C); $\mathrm{MS}(\mathrm{EI}+) m / z=215\left[\mathrm{M}^{+}\right], 184,158,130,102 ; \mathrm{HRMS}(\mathrm{ES}+) m / z=216.1120\left[\mathrm{MH}^{+}\right]$, calcd. for $\mathrm{C}_{12} \mathrm{H}_{14} \mathrm{~N}_{3} \mathrm{O}^{+}$216.1137; IR(KBr) $2926 \mathrm{~cm}^{-1}, 2858 \mathrm{~cm}^{-1}$.

\section{Acknowledgements}

We are grateful David Durham for the linguistic improvement of the manuscript. One of the authors (A.M.) expresses her thanks for support through a Sanofi Aventis Fellowship.

\section{References}

1. Selected reviews: (a) Schündehütte, K. H. In Houben-Weyl; Stroh, R. Ed.; Thieme: Stuttgart, 1965; Vol. 10/3, p 771. (b) Buncel, E. In Mechanisms of Molecular Migrations; Thyagarajan, B. S. Ed.; Interscience: New York, 1968; Vol. 1, p 61. (c) Cox, R. A.; Buncel, E. In The Chemistry of Hydrazo, Azo and Azoxy Groups; Patai, S. Ed.; Wiley: New York, 1975; Vol. 2; p 808. (d) Özen, A. S.; Erdem, S. S.; Aviyente, V. Struct. Chem. 1998, 9, 15.

2. Wallach, O.; Belli, L. Chem. Ber. 1880, 13, 525. 
3. (a) Baudisch, O.; Fürst, R. Chem. Ber. 1912, 45, 3426. (b) Cumming, W. M.; Ferrier, G. S. J. Chem. Soc. Abst. 1925, 127, 2374. (c) Badger, G. M.; Buttery, R. G. J. Chem. Soc. 1953, 2156.

4. Yamato, J.; Nishigaki, Y.; Umezu, M.; Matsuura, T. Tertahedron 1980, 36, 3177.

5. Singh, J.; Singh, P.; Boivin, J. L.; Gagnon, P. E. Can. J. Chem. 1963, 41, 499.

6. (a) Duffey, D.; Hendley, E. C. J. Org. Chem. 1968, 33, 1918. (b) Stevens, T. E. J. Org. Chem. 1968, 33, 2667. (c) Hendley, E. C.; Duffey, D. J. Org. Chem. 1970, 35, 3579. (d) Keum, S. R.; Lee, H. I. J. Korean Chem. Soc. 1993, 37, 148.

7. (a) Cox, R. A.; Dolenko, A. J.; Buncel, E. J. Chem. Soc., Perkin Trans. 2 1975, 53, 471. (b) Buncel, E.; Cox, R. A.; Dolenko, A. J. Tetrahedron Lett. 1975, 3, 215.

8. (a) Buncel, E.; Keum, S. R. J. Chem. Soc., Chem. Commun. 1983, 578. (b) Buncel, E.; Keum, S. R.; Rajagopal, S.; Klepek, E. Can. J. Chem. 2008, 86, 298.

9. Harsányi, K.; Gönczi, Cs.; Korbonits, D. Justus Liebigs Ann. Chem. 1973, 2, 190.

10. (a) Loones, K. T. J.; Maes, B. U. W.; Dommisse, R. A.; Lemière, G. L. F. Chem. Commun. 2004, 2466. (b) Loones, K. T. J.; Maes, B. U. W.; Dommisse, R. A. Tetrahedron 2007, 63, 8954. (c) Bogányi, B.; Kámán, J. J. Heterocycl. Chem. 2009, 46, 33.

11. CCDC-749526 contains the supplementary crystallographic data for compound $\mathbf{1 2}$. These data can be obtained free of charge from The Cambridge Crystallographic Data Centre via www.ccdc.cam.ac.uk/data_request/cif.

12. Iijima, C. Yakugaku Zasshi 1967, 87, 942.

13. (a) Moskalenko, G. G.; Sedova, V. F.; Mamaev, V. P. Izv. Akad. Nauk SSSR, Ser. Khim. 1987, 701. (b) Moskalenko, G. G.; Sedova, V. F.; Mamaev, V. P. Bull. Acad. Sci. USSR, Div. Chem. Sci. (English Trans.) 1987, 36, 642.

14. Iijima, C.; Kyō, T. Chem. Pharm. Bull. 1989, 37, 618. 